\title{
UM DIÁLOGO SOBRE O EQUÍVOCO DE MEMÓRIA
}

\author{
Leandro De Bona Dias ${ }^{1^{\star}}$ \\ Mário Abel Bressan Júnior ${ }^{1^{* *}}$ \\ ${ }^{1}$ Universidade do Sul de Santa Catarina, Tubarão, SC, Brasil
}

\begin{abstract}
Resumo
O presente artigo tem como objetivo discutir as relações entre memória e literatura no texto autobiográfico a partir da inserção do conceito de equívoco de memória. Assumindo o diálogo como forma de provocação, procuro responder algumas questões acerca das características do que chamo equívoco de memória, conceito forjado com base nas ideias de perspectivismo ameríndio e de equívoco controlado, ambas desenvolvidas pelo antropólogo Eduardo Viveiros de Castro. A leitura que defendo encara o texto autobiográfico como sendo constituído por um processo de intensa alteridade, de diferença e não de semelhança, e o seu autor como um tradutor do passado, cujo trabalho se torna legível somente por meio do equívoco.

Palavras-chave: Equívoco de memória; Literatura; Autobiografia
\end{abstract}

\section{A DIALOGUE ABOUT MEMORY EQUIVOCATION}

\begin{abstract}
This article aims to discuss the relations between memory and literature in the autobiographical text based on the concept of memory equivocation. Taking dialogue as a way to provoke, I try to answer some questions about the characteristics of what I call memory equivocation, a concept based on the ideas of Amerindian perspectivism and controlled equivocation developed by the anthropologist Eduardo Viveiros de Castro. The argument that I stand for take the autobiographical text as built by an intense process of otherness and difference instead of similarity, and its author as translator of the past, whose the work becomes legible only because of the equivocation.
\end{abstract}

Keywords: Memory equivocation; Literature; Autobiography

\footnotetext{
"Licenciado em Letras: Português/Inglês pela Universidade do Extremo Sul de Santa Catarina (UNESC); Mestre em Educação pelo Programa de Pós-Graduação em Educação (UNESC). Doutorando no Programa de Pós-Graduação em Ciências da Linguagem da Universidade do Sul de Santa Catarina (UNISUL). Membro dos grupos de pesquisa Memória, Afeto e Redes Convergentes (MARC-UNISUL) e Littera: Correlações entre Cultura, Processamento e Ensino: a linguagem em foco (UNESC). Bolsista do Programa de Suporte à Pós-Graduação de Instituições Comunitárias de Educação Superior - PROSUC/CAPES. E-mail: debona12@ hotmail.com. ORCID: http://orcid.org/0000-0003-4200-3886.

${ }^{* *}$ Doutor em Comunicação Social (PUC-RS). Líder do Grupo de Pesquisa Memória, Afeto e Redes Convergentes (MARC). Professor no Programa de Pós-Graduação em Ciências da Linguagem da UNISUL Autor dos livros: Memória Teleafetiva (2019); e Minhas Memórias Afetivas: dê de presente para alguém ou guarde-as para si. E-mail: marioabelbj@gmail.com. ORCID: http://orcid.org/0000-0002-8309-1723.
} 


\section{Um início de conversa}

O presente texto tem como inspiração um ensaio escrito por bel hooks em seu livro Ensinando a transgredir: a educação como prática da liberdade (2013). Nele, a autora cria um diálogo imaginário entre Gloria Watkins, seu nome de registro, e bel hooks, nome que adotou como escritora, para propor uma conversa sobre Paulo Freire. Ela justifica, deste modo, a sua escolha: "Quis escrever sobre Paulo e sua obra deste jeito porque ele me proporciona uma intimidade - uma familiaridade - que não me parece possível alcançar na forma de ensaio" (hooks, 2013, p. 65). Minha opção aqui não compartilha da mesma justificativa, mas nasce, primeiramente, de minhas inquietações e dúvidas a respeito do entrelaçamento dos temas memória, literatura e autobiografia dentro daquilo que proponho em minha tese como sendo o equívoco de memória.

Obviamente, o recurso ao diálogo não constitui nenhuma novidade, estando o seu exemplo mais explícito na Grécia, quando, a partir do método socrático, foi adotado para pensar a filosofia. É interessante notar que esse tipo de recurso nunca abriu mão de elementos ficcionais - basta olhar para as discussões ainda existentes sobre o quanto há de Sócrates nos diálogos escritos por Platão e o quanto há do próprio Platão utilizando a figura do mestre para professar seu pensamento. Nesse sentido, o diálogo flerta com a ficção, a memória e a alteridade, posto que nele esta última característica é a responsável por instituir o tom do texto em sua própria estrutura, que faz a palavra flutuar entre os seus interlocutores. Reside aí minha segunda justificativa para a escolha da escrita em forma de diálogo: a questão da alteridade.

Tal como o uso do diálogo, também não é novidade que o nosso pensamento opera de modo dialógico. Isso pode ser lido nas contribuições teóricas de Mikhail Bakhtin (2006) e nas de Paulo Freire (1987), pensadores que compreendem a linguagem e a própria identidade como um fenômeno que se dá por meio do outro, da alteridade. Ora, essa alteridade não se refere somente ao que é externo a mim, mas também ao próprio diálogo interior, o "diálogo consigo mesmo", como dirá Bakhtin (2006), e um diálogo, uma palavra, que também é práxis, como em Freire (1987), ideia que é reforçada no que escreve Jorge Larrosa Bondía (2002, p. 21), "pensar não é somente 'raciocinar' ou 'calcular' ou 'argumentar', como nos tem sido ensinado algumas vezes, mas é sobretudo dar sentido ao que somos e ao que nos acontece. E isto, o sentido ou o sem-sentido, é algo que tem que ver com as palavras".

É por isso que escrever é fazer sentido de si e do outro, de si e do mundo. Portanto, parece-me muito apropriado pensar a escrita acadêmica também como um diálogo entre o próprio pesquisador consigo mesmo e com os demais autores com os quais estabelece relações em seu texto. Em realidade, a forma pela qual decidi, neste texto, expor (e me expor) talvez chame a atenção apenas por isso, pela forma com que se apresenta, possuindo duas vozes (e várias outras) muito bem marcadas: a de quem pergunta e a de quem responde. Retomando a ideia de dialogismo em Bakhtin, diria que a adoção dessa forma visa a trazer para o primeiro plano o dialogismo pelo qual se compõe todo e qualquer discurso. 
Após esta introdução, que se estendeu mais do que eu havia planejado, passo ao diálogo durante o qual procuro responder algumas questões acerca das características do equívoco de memória, conceito que ainda está sendo semeado e para o qual o presente texto busca ser um meio de cultivo diante da germinação incerta.

Gostaria de iniciar falando sobre o tema da memória. Você afirma, em um de seus textos, que a escrita da memória é sempre uma tradução, portanto sempre será distinta do momento vivido, jamais conseguindo recompor o acontecimento tal como ele foi vivido. Tomando esse ponto de vista, o que diferenciaria a memória, em sentido mais geral, daquilo que você chama de equívoco de memória?

Eu diria que o equívoco de memória, como proponho, constitui, basicamente, um entendimento, uma posição, uma leitura que encara essa incapacidade de retomar o vivido na escrita não como "falha", "erro", mas como uma possibilidade de fazer a tradução desse passado, buscando enfatizar em lugar da semelhança (seja com o autor, seja com os fatos vividos) a profunda alteridade pela qual o texto literário autobiográfico é composto.

Certo. Mas se essa é a única possibilidade de se "escrever o passado", como você também já afirmou em outro momento, então não se poderia dizer que todo e qualquer esforço de rememoração seria, portanto, um equívoco de memória, já que toda tentativa de lembrar de algo esbarraria sempre nessa impossibilidade de se ter acesso ao fato vivido de modo integral?

Penso diferente. Defendo a ideia de que o equívoco de memória é constituído por aqueles momentos em que, na narrativa do vivido, manifesta-se textualmente $o$ processo pelo qual se tenta retomar essa memória. Ou seja, quando se explicita o processo da tradução. É a essa tentativa de transcrever esse vivido que chamo equívoco de memória.

Para tentar esclarecer esse ponto, no qual você corretamente insiste, proponho uma analogia com o processo de tradução de um texto de uma língua para outra. No seu trabalho, é comum que o tradutor se veja, ora ou outra, em dúvida sobre qual vocábulo usar para traduzir determinada palavra ou expressão. Diante dessa dúvida, empreende-se, por meio de pesquisa, de aconselhamento, de testes, uma busca para que se consiga encontrar um termo semelhante o suficiente para que o sentido do texto original seja mantido. Durante esse processo, o tradutor terá que, invariavelmente, realizar escolhas, adições ou omissões ao texto original. Ora, sabe-se que jamais as palavras do texto original serão iguais às usadas na tradução. A identidade (no sentido estrito de semelhança) entre os dois textos, portanto, não existe. Tudo isso constitui o processo de tradução e, ao final, o que se espera é que o texto se torne legível para uma pessoa que domina apenas o idioma para o qual se verteu o original. Daí podemos depreender que a tradução feita é falha porque não há identidade entre ela e o texto original? A resposta é 
não. O resultado final da tradução constitui, portanto, um equívoco, do ponto de vista da identidade entendida como semelhança buscada, mas também um texto que, graças ao trabalho do tradutor, permite que seu conteúdo seja acessado por quem não domina o idioma no qual ele foi escrito originalmente. $\mathrm{O}$ equívoco, portanto, não é a falha, o erro, mas a própria condição de legibilidade daquilo que se quer comunicar. Regressando dessa analogia para responder sua pergunta, diria que o vivido se assemelha ao texto original, que se encontra em uma língua acessível apenas ao indivíduo que viveu esse vivido.

Antes de prosseguir, gostaria de registrar que compreendo as complexas relações entre memória coletiva e individual, e que a obra de Maurice Halbwachs (1990) é de suma importância nessa discussão, mas, para fins de analogia, seguirei com a imagem da pessoa que quer expor a alguém uma memória de seu ponto de vista individual, aceitando por ora o risco de tal simplificação. Bem, a esse sujeito surge, então, a necessidade de comunicar essa memória, esse texto, mas como fazê -lo se a língua em que ele está escrito pode apenas ser lida pelo indivíduo que tem esse vivido em sua memória individual? A resposta: por meio de uma tradução.

Como já disse anteriormente, a tradução tem como um de seus processos as escolhas, as omissões, as adições, e o mesmo se aplica à tradução do vivido para o texto escrito. (É importante frisar este ponto: o foco de minha pesquisa e de tudo o que falo quando me refiro a uma tradução do vivido é sempre o texto literário). Essa tradução se realiza e, tal qual na tradução de um texto de um idioma para o outro, o objetivo é comunicar ao leitor o que se pretendia dizer no texto original. Ambos os processos, que estou chamando aqui de tradução textual e tradução do vivido, compartilham, portanto, do mesmo objetivo e do mesmo equívoco, visto que jamais serão as traduções exatas de seus textos originais.

Retorno agora ao início da resposta para dizer que o que chamo de equívoco de memória são os momentos em que no texto autobiográfico podemos ver o trabalho de tradução do vivido. Voltando à comparação, é como se pudéssemos ver no texto traduzido as marcas do esforço de sua tradução (no caso das traduções textuais as notas de rodapé poderiam ser um exemplo disso, talvez), esforço que é ao mesmo tempo a confissão da alteridade, portanto do equívoco, e a comunicação entre duas experiências distintas e inigualáveis.

Buscando resumir minha resposta, diria que a impossibilidade de, no texto escrito, retomar de modo exato o vivido é comum a toda memória, mas isso é escamoteado, escondido, tendo em vista que quem narra pretende (pelo menos na maioria das vezes) que o seu leitor confie no que está escrito como sendo aquilo que foi vivido. Apenas nos momentos em que surgem no texto os rastros desse processo de tentativa de tradução é que afirmo estar presente o equívoco de memória.

Se entendi corretamente, nesta analogia com a tradução, o passado seria o equivalente ao texto em sua língua original, enquanto o momento da escrita, ou o resultado dela, corresponderia ao texto na língua-alvo. Mas no caso de uma escrita autobiográfica não ocorreria uma autotradução? Isso não traria outras implicações éticas, estéticas? 
Essa pergunta possui dois méritos: o primeiro é o de permitir a confissão de minha ingenuidade quanto às teorias da tradução; o segundo é o de adicionar à minha pretensa analogia um elemento complicador ao utilizar o termo "autotradução". Apesar de não ser um especialista no assunto, acredito que o ato de traduzir não se resume a um processo mecânico de substituição de palavras. Ao citar os testes, escolhas e omissões que ocorrem durante o processo tradutório, talvez tenha esquecido de enfatizar o componente político, ético e estético que envolve esse procedimento. Isso é vital para o que quero propor, e tal postura encontra-se também no que escreve Eduardo Viveiros de Castro (2005, p. 153):

Traduzir é presumir que há desde sempre e para sempre um equívoco; é comunicar pela diferença, em vez de silenciar o Outro, ao presumir uma univocidade originária e uma redundância última - uma semelhança essencial - entre o que ele e nós "estávamos dizendo".

Conforme o autor, a tradução não tem a ver com a busca e o encontro de uma semelhança, mas com a instauração de uma profunda diferença que estabelece uma relação. Seria algo como o que escreve Gayatri Spivak (2005, p. 42): "traduzir é necessário, mas impossível". A perspectiva de uma tradução do passado se coaduna com esse aspecto da impossibilidade, mas de uma impossibilidade que estabelece uma relação em que antes não havia nada. É daí que me veio a ideia de tomar a imagem da tradução como metáfora para explicar a lógica do equívoco de memória.

Sobre as escolhas éticas e estéticas, penso que elas estão presentes no texto autobiográfico, naquilo que é contado e também contido, como dirá Tânia Regina de Oliveira Ramos no delicioso artigo Meninas atrevidas: o que é que não vão dizer? Tal jogo de palavras reforça a ideia do equívoco de memória como um momento do texto em que se pode perceber a profunda diferença pela qual se funda o sentido. Outra pérola de Tânia: “'lembrar do eu' equivale a 'lembrar doeu”" (RAMOS, 1990, p. 23). As palavras homófonas fazem menção aos silêncios e às ausências nos textos literários da memorialística feminina brasileira, marcas textuais que apresentam o relato de uma vida que é contada, mas ao mesmo tempo escondida, encriptada por meio de uma autocensura dessas vozes. No caso do equívoco de memória a ideia não é encontrar a chave de tais enigmas sugeridos pelos vestígios, mas de lê-los como marcas do funcionamento de uma tradução do passado. Volto ao ponto inicial da pergunta para dizer que, do ponto de vista teórico que assumo, a tradução é um processo marcado por uma atitude ética, uma vez que aceita a impossibilidade de uma semelhança e reconhece a alteridade como constitutiva do exercício tradutório e não só dele, mas da própria existência, uma tradução de si que não apaga o outro, seja o outro-si do passado, seja o outro que compõe a própria identidade, e a tradução é também um processo estético porque a autobiografia se realiza pela materialidade, pela forma, pelo arranjo da palavra, do silêncio.

Bem, como você falou de minha insistência neste tema, não irei desapontá-lo. Pergunto: se considerarmos que o equívoco de memória somente pode ser per- 
cebido nos momentos em que, como você disse, é possível enxergar esses rastros da tradução, isso significa que onde não os vemos haveria um sucesso na correspondência entre o fato que se quis lembrar e o registro escrito desse fato?

Bom, afirmar isso seria tomar o equívoco de memória, portanto, como um insucesso, concorda? Pois bem, do ponto de vista que assumo, não é possível julgar como bem ou malsucedido um texto no qual se busca realizar uma tradução do vivido, isso porque a narrativa, ao ser registrada, é já o resultado de um trabalho da memória, que é, embora possa dispor da ajuda de elementos como fotos, vídeos etc., a única ferramenta disponível para organizar esse vivido, para traduzi-lo, como já havia mencionado na resposta anterior. Aliás, já que fiz referência à questão anterior, permita-me citar novamente o autor no qual baseio as concepções de tradução e de equívoco com as quais trabalho. Ambas as noções estão em Eduardo Viveiros de Castro, antropólogo brasileiro com o qual tive o primeiro contato por meio de um artigo seu chamado Equívocos da identidade (2005). Nesse texto é que encontrei a primeira pista para pensar a memória a partir da alteridade, ou seja, como algo diferente daquilo que foi.

É óbvio, você pode dizer, qualquer um sabe que uma memória não poderá ser jamais a mesma coisa que o momento vivido. Mas o que me chamou a atenção foi o modo como o autor propunha a compreensão dos termos identidade, alteridade e tradução. Infelizmente é impossível resumir assim de modo tão grosseiro o pensamento de Viveiros de Castro, mas gostaria de citar aqui a sua ideia de perspectivismo ameríndio, conceito forjado com base no modo como os povos amazônicos compreendem o mundo e a partir do qual a alteridade se sobrepõe à identidade. Ou seja, se para nós a identidade é importante porque funda uma espécie de irmandade, de comunhão, para os povos ameríndios o que interessa é a diferença. É com o diferente que eu aprendo, é com ele que posso estabelecer uma relação em que haja troca.

É bom pontuar que estou aqui me arriscando no campo da Antropologia, por isso me reservo o direito de ser corrigido a qualquer momento por alguém mais competente nessa área. Mas, se minha leitura é correta, a tradução, segundo Viveiros de Castro (2005), deverá ser entendida como um trabalho que tenta aproximar perspectivas, mas sem a pretensão de alcançar uma identidade entre elas, pois, como havia dito, a diferença é que funda a possibilidade de relação com o outro. Aqui, sinto-me obrigado a trazer a voz do autor em meu auxílio.

Só pode haver relação entre o que difere, e porque difere. Nesse caso, a tradução passa a ser uma operação de diferenciação - de produção da diferença que liga os dois discursos na exata medida em que eles não estão dizendo a mesma coisa, em que eles visam exterioridades discordantes, para além das homonímias equívocas entre eles (VIVEIROS DE CASTRO, 2005, p. 159).

É com base nisso que podemos entender a palavra equívoco no título do artigo Equívocos da identidade, que acabo de citar, não com o significado de erro, falha, 
mas como a condição única de tradução entre duas perspectivas que não poderão jamais se fundir, ser idênticas.

É por isso que tomo emprestados esses termos de Viveiros de Castro (2005) e foi a partir deles que construí a seguinte conjectura: ora, se a memória opera tentando recuperar algo vivido no passado e que jamais poderá ser retomado da mesma forma, existe aí uma relação de diferença. E se, adotando as premissas do perspectivismo ameríndio, a tradução é o meio pelo qual se pode fundar uma relação onde antes não havia nada (digamos onde antes não havia memória), por que não pensar a memória como algo que opera por meio da tentativa de tradução de um passado vivido e que só poderá ser retomado sob a marca do equívoco, ou seja, daquilo que possui na sua diferença a possibilidade de se relacionar com o presente? Foi a partir dessa proposição, agora já rememorada como equívoco, se me permite a brincadeira, que surgiu a semente que viria a ser plantada no solo de minha pesquisa. Peço desculpas novamente se me afastei da sua última questão, mas seria imperdoável não citar a influência de Eduardo Viveiros de Castro.

Sem problema, acho que a referência ao texto ajuda a compreender um pouco mais a respeito da própria palavra "equívoco", comumente usada no sentido mesmo de um engano.

Exato. Acredito que o sinônimo que você acabou de usar é perfeito.

Se formos olhar nos dicionários, a definição de equívoco recai sobre a ideia de algo ambíguo, duvidoso, de duplo sentido, e nem todos trazem a palavra "erro" como um dos sentidos possíveis. No entanto, penso que no uso cotidiano, ao menos na minha experiência, é exatamente a esse sentido de erro que a palavra está primeiramente atrelada na maioria das vezes. Por isso, acho que o sinônimo que você usou é adequado ao que acabei de expor. Mais adequada ainda é a definição trazida em alguns compêndios como o Houaiss (2011) e o dicionário de Evanildo Bechara (2011), em que o equívoco é descrito como uma coisa ambígua, que pode ter mais de um sentido. Ora, e não seria exatamente isso o que se pode perceber no ato de rememorar? Ao escrever um fato vivido, o autor de um texto não estaria pondo no papel o resultado de algo que é e ao mesmo tempo não é aquela coisa que se quer lembrar? Não seria também aquilo que está no texto a presença de uma ausência, para voltar às ideias de Platão (1973) no diálogo Teeteto, por exemplo? Aliás, se me permite mais uma divagação, já que toquei no assunto do texto escrito, do texto literário mais especificamente, creio que seria possível estender essa ideia de presença de uma coisa ausente para a própria figura do autor.

Veja: quando uma pessoa senta e escreve sobre o que viveu, essa pessoa, que escreve, já não é a mesma que viveu, e depois que acabar de escrever, quando o texto for lido (por ela ou por outro leitor qualquer) já a pessoa que escreveu também não será a mesma em relação ao passado que recobre agora o próprio ato da escrita. É por isso que me ocorre pensar a figura do autor de um texto autobiográfico como duplamente outra. 
Construo essa hipótese também me apoiando em Paul Ricouer (2007) quando analisa as ideias de Edward Casey sobre o que seria a memória reconhecida ou o reconhecimento da memória (recognizing é o termo usado por Casey). Essa operação ocorreria no momento em que o sujeito que tenta rememorar algo consegue atingir o seu objetivo e finalizar sua busca, mas, escreve Ricoeur (2007, p. 56), neste instante "a 'coisa' reconhecida é duas vezes outra: como ausente (diferente da presença) e como anterior (diferente do presente). E é como outra, emanando de um passado outro, que ela é reconhecida como a mesma".

Se compreendermos assim a figura do autor, será possível imaginá-lo, ao ler o seu texto, como um autor duplamente outro, porque não poderá coincidir (mais uma vez a questão da identidade surge) com a pessoa que é quando está sendo lido, e nem com a pessoa que foi no passado traduzido em seu texto.

De fato há várias conexões possíveis nesse campo da memória. Mas, permitame voltar àquela questão que havia proposto lá atrás e que, do meu ponto de vista, ainda está um pouco confusa. Você disse que o equívoco de memória se caracterizaria pelos momentos em que se vê esse processo de tradução do passado. Repito a pergunta: isso significa que onde não se pode ver esse rastro haveria um sucesso na correspondência entre o fato que se quis lembrar e o registro escrito desse fato?

Importante voltar a ela. É uma excelente questão e pode me ajudar a mostrar o modo como, até então, compreendo, dentro da minha armação teórica, a memória e o seu funcionamento. De novo vou aproveitar uma palavra que você usou: sucesso. Na sua pergunta, me corrija se estiver errado, ela parece definir uma memória que foi buscada e recuperada, um número de telefone do qual se precisa, uma nome de um filme que se quer rever etc. É isso?

Sim, concordo.

Peço desculpas se me repito, mas quando comecei a respondê-lo e acabei me desgovernando para a referência a Eduardo Viveiros de Castro, disse que aceitar a premissa da sua questão seria julgar possível uma memória bem-sucedida em oposição ao equívoco de memória, e que não poderia aceitar tal ideia. Bem, tentarei desenvolver um pouco mais essa minha discordância.

Para tanto, vou, novamente, recorrer a Paul Ricoeur (2007, p. 40) para dizer com ele que: "não temos nada melhor que a memória para significar que algo aconteceu, ocorreu, se passou antes que declarássemos nos lembrar dela". E, ainda no mesmo livro, o autor dirá a respeito das perguntas sobre a verdade contida na memória:

Chamemos de fidelidade essa busca de verdade. Falaremos, doravante, da verdade-fidelidade da lembrança para dizer essa busca, essa reivindicação, esse claim, que constitui a dimensão epistêmico-veritativa do orthos logos da memória (RICOEUR, 2007, p. 70, grifos do autor). 
Bom, mesmo não me considerando um fenomenologista e estando atento às armadilhas impostas pelo trabalho com categorias como verdade e fidelidade, reconheço a importância da fenomenologia da memória desenvolvida por Ricoeur (2007) e tomo emprestado dele a fala acima para, a partir dela, responder que, dentro de minha proposta, a memória será sempre bem-sucedida. É importante pontuar que Ricoeur desenvolve com muito mais vigor o tema a partir da leitura de outros grandes pensadores da memória como Henri Bergson e suas ideias de memória feliz e memória infeliz usadas para se referir, respectivamente, a uma espécie de encontro ou de não encontro da lembrança procurada.

Preciso dizer também que existem várias outras formas de se conceber teoricamente as ideias de sucesso e de fracasso com relação à memória, mas, como é preciso realizar escolhas, dentro do que proponho como equívoco de memória e procurando construí-lo como uma maneira de se pensar e ler a literatura autobiográfica, posso dizer que a memória, na perspectiva que adoto, deve ser tomada como um processo bem-sucedido. Obviamente podemos prever situações em que se queira lembrar de alguma coisa e, por mais que haja um esforço, essa memória não surja. Não desconsidero essa hipótese, mas lembro que a minha proposta se aplica à literatura, ao texto escrito, é ali que o equívoco de memória poderá ser visto. Pois bem, se o texto está escrito, assumo que a memória operou uma tradução do vivido, sendo assim, é preciso entendê-la como tendo alcançado seu objetivo com sucesso, do contrário eu não teria o objeto sobre o qual se apoia o próprio conceito que busco desenvolver.

Entendo. Contudo, com base no final da sua resposta, dizer que a memória será sempre bem-sucedida implica, necessariamente, que haja o polo oposto, uma memória malsucedida. Então você admite essa possibilidade? E sendo assim, volto a insistir, o equívoco de memória não poderia ser considerado o resultado de uma memória malsucedida?

A sua insistência me faz refletir sobre a dificuldade imposta por determinadas palavras e sobre o próprio modo de pensar que parece não prescindir de determinados pares antagônicos.

Eu tenderia a evitar que se pusesse nesses termos uma interpretação do acabei de dizer, mas, de qualquer forma, compreendo que a sua maneira de ler minha resposta se mostra válida. Se digo que a memória é sempre bem-sucedida, fica nas entrelinhas a ideia de que há, sim, em potencial uma memória malsucedida. Me dou por vencido neste ponto. Contudo, volto a insistir, o equívoco de memória não pode ser entendido como uma falha em traduzir o vivido, o que constituiria um paradoxo, visto que a existência do conceito pressupõe um texto traduzido no qual exista vestígios do processo de tradução.

Compreendo. Bom, pegando carona nessa última resposta, passo agora a uma questão mais voltada para a materialidade com a qual você se propõe trabalhar: o texto literário. Mesmo sabendo que não há resposta definitiva, sinto 
que devo fazer essa pergunta: o que é literatura? Ou melhor, como você concebe teoricamente a literatura dentro de seu projeto?

Posso dizer que estenderia essa sua observação sobre não haver resposta definitiva a todas as perguntas anteriores. Mas, brincadeiras à parte, essa questão é bastante delicada e mexe com as convicções de muita gente. Vamos lá.

Em primeiro lugar, e já para aliviar um pouco o peso da pergunta, permito-me fazer um recorte dentro do imenso tecido da literatura e me deter nesse pedaço o qual se pode denominar de literatura autobiográfica. Aliás, outro autor já realizou tal operação com muito maior competência do que eu, refiro-me ao francês Philippe Lejeune. Com todas as ressalvas e reparos que se possa fazer aos seus esquemas e ao próprio conceito que ele sugere de pacto autobiográfico, não se pode falar em autobiografia sem citá-lo. É o que faço aqui para mostrar o modo como ele define esse gênero: "narrativa retrospectiva em prosa que uma pessoa real faz de sua própria existência, quando focaliza sua história individual, em particular a história de sua personalidade" (LEJEUNE, 2014, p. 16). O próprio autor irá mais tarde olhar com reservas e revogar certos pontos dessa definição, como, por exemplo, o fato de desconsiderar os textos em verso como uma possibilidade de escrita autobiográfica. No entanto, é a partir daí que Lejeune (2014) irá desenhar o seu famoso pacto autobiográfico, que ocorre quando o leitor aceita que o que está sendo narrado na obra corresponde (é semelhante) à vida do autor, ainda que em forma de recorte.

Não preciso retomar aqui toda a minha argumentação já gasta em outros momentos para explicar a impossibilidade da identidade, no sentido de semelhança, entre o autor e seu texto autobiográfico. Nesse ponto, discordo ligeiramente da premissa do pacto autobiográfico. Por outro lado, se entendo a questão do pacto como sendo algo que abarca o caráter de alteridade no qual se compõe a narrativa autobiográfica, aí estou com Lejeune. Mas essa discussão poderia se alongar demasiadamente.

De qualquer maneira, aceitando ou não o pacto, não posso me furtar de todo o arcabouço teórico que Lejeune (2014) oferece e que é fundamental para pensar as questões relacionados a uma escrita de si. Com isso em vista, destacaria aqui, mesmo que brevemente, um ponto (na verdade se desdobrando em dois) que julgo importante no que o autor escreve sobre o tema.

Esse ponto está relacionado à compreensão do próprio sujeito que escreve. Acredito que a palavra, a linguagem, é o meio pelo qual nos constituímos e fazemos sentido de nós mesmos e do mundo. O sujeito que escreve, o autor, constrói a sua vida narrativamente, assim como todos nós o fazemos, afinal, lembrando aqui Marina Colasanti (2000) em seu conto A moça tecelã, estamos a todo o momento contando para nós mesmos quem nós somos, tecendo e destecendo, fiando e desfiando as narrativas de nossas vidas. Lejeune (2014, p. 121) parece concordar com isso quando escreve que "todos os homens que andam na rua são homens-narrativa, é por isso que conseguem parar em pé”. Seguindo a metáfora do autor, eu diria que também é preciso narrar para não cair no esquecimento de si, esquecimento contra o qual a memória luta incessantemente. 
O desdobramento disso (segundo ponto) diz respeito ao papel da imaginação nos relatos autobiográficos. Paul Ricoeur (2007), ao tratar desse tema, pontua a dificuldade em distinguir memória e imaginação e conclui que, embora ambos operem em conjunto e até dependam um do outro, a diferença entre eles está na relação com um evento marcadamente passado. Ou seja, ao tentar lembrar de uma coisa eu a imagino, mas só posso imaginá-la presa, de certa forma, ao tempo passado em que essa coisa ocorreu. Por exemplo: ao tentar me lembrar da primeira ida ao cinema posso imaginar como era a entrada do lugar onde o filme estava sendo exibido, a poltrona em que sentei, o que comi enquanto assistia ao filme etc., mas todas essas coisas imaginadas estão atreladas a um ano específico, a um lugar específico. No caso da imaginação, essa marcação temporal não existe, o que a torna mais livre. $\mathrm{O}$ que tentei explicar poderia ser assim resumido:

A imaginação [está] voltada para o fantástico, a ficção, o irreal, o possível, o utópico; a [...] memória, voltada para a realidade anterior, a anterioridade que constitui a marca temporal por excelência da "coisa lembrada", do "lembrado" como tal (RICOEUR, 2007, p. 26, grifos do autor).

Acredito que a distinção é válida, conquanto não se faça um julgamento de valor em que a balança pese mais para o lado da memória. Digo isso porque a compreensão que tenho é de que, mesmo nesses momentos em que a marcação temporal parece engessar de alguma forma o modo como se imagina o que foi vivido, será impossível dizer que não estamos também diante do terreno da ficção. Conforme Antonio Candido (2011) (e aqui faço uma paráfrase), não há ser humano que possa passar vinte e quatro horas sem que se entregue em algum momento à imaginação, à ficção. Esse argumento se prova a cada vez que, estando no trânsito, imaginamos o que iremos fazer ao chegar em casa, a cada vez que planejamos uma viagem de férias ou quando estamos com a cabeça no travesseiro pensando nas ações do dia seguinte.

É claro que nem toda imaginação é da mesma ordem e funciona do mesmo modo, mas o que defendo é que a memória irá operar, no caso da autobiografia, também por meio de enxertos imaginários. Essa imagem me surgiu da leitura, que acabo de iniciar, do livro Becos da Memória, autobiografia da professora e escritora carioca Conceição Evaristo. Na página de apresentação da obra, ela escreve:

Também já afirmei que invento sim e sem o menor pudor. As histórias são inventadas, mesmo as reais, quando são contadas. Entre o acontecimento e a narração do fato, há um espaço em profundidade, é ali onde explode a invenção. Nesse sentido venho afirmando: nada que está narrado em Becos da Memória é verdade, nada que está narrado em Becos da Memória é mentira. Ali busquei escrever ficção como se estivesse escrevendo a realidade vivida, a verdade (EVARISTO, 2017, p. 11).

É brilhante o modo como, em poucas linhas e de forma profundamente poética, Conceição Evaristo resume boa parte daquilo que venho tentando explicar em 
nossa conversa de um jeito tão pouco sensível no nível da linguagem empregada. Isso me lembra Paulo Freire, quando em uma de suas conferências disponíveis em vídeo na internet diz que é preciso "artistizar a vida" (PROF., 2014). Eu pediria a ele licença para acrescentar: é preciso artistizar a ciência. Mas temo dever agora voltar à minha linha de raciocínio depois desse momento de alívio literário.

Pois bem, dizia eu que, para explicar como entendo a autobiografia, dois pontos me pareciam úteis na reflexão de Lejeune (2014). O primeiro, a importância da narrativa na construção do sujeito e do mundo em que ele habita e que habita nele; o segundo, a necessidade de imaginar e a necessidade de ficcionar que compõem o ato de narrar uma vida. À memória, esses dois elementos servem como alimento, visto que lembrar é contar uma história para si, para o outro, para o outro-si (se retomarmos a perspectiva do autor/narrador como duplamente outro), história que necessita de elementos da imaginação para traduzir o vivido em texto legível no presente.

Apesar dos interessantes apontamentos, sinto que fui vítima de um drible nessa questão, você me respondeu mesmo o que seria a autobiografia na sua perspectiva?

Em linhas gerais, creio ter respondido, mas se o que esperava era uma definição, para não parecer antipático lhe deixei com a de Lejeune (2014) logo no início da minha resposta. De minha parte, prefiro não arriscar com medo de que aconteça comigo o mesmo que se passou com o próprio autor francês, que se viu vítima de seu conceito, como ele mesmo descreve em uma espécie de autoanálise no texto O pacto autobiográfico, 25 anos depois (LEJEUNE, 2014). Acredito que preciso me debruçar um tanto mais sobre a questão antes de sair disparando conceitos e formulações das quais possa me arrepender.

Entendo. Mas sobre o equívoco de memória você me pareceu bem categórico. Por que ao falar dele não lhe afligiu essa possibilidade do arrependimento?

Tem razão, bem lembrado. A resposta talvez resida na necessidade humana de realizar uma contenção do sentido. Stuart Hall (2016) fala sobre isso ao tratar dos estereótipos. Segundo ele, a estereotipagem é uma forma de olhar para as características mais simples, mais visíveis e, por isso mesmo, mais facilmente compreensíveis de uma pessoa e parar por ali, buscando apreender o sentido e contê-lo. A tentativa de se fazer ciência pode, por vezes, ir por esse caminho, tentando simplificar as coisas para melhor fazê-las caber dentro de determinada teoria.

É óbvio que não podemos também viver na eterna rasura da linguagem, no seu deslizamento, por isso tentamos, minimamente, conceituar as coisas ao nosso redor. Enfim, dei toda essa volta para tentar justificar que o conceito é uma necessidade teórica, um caminho para, inclusive, contestar o próprio conceito que se pretende criar. Porém, para questionar é preciso cogitar, conjecturar, e imaginar também. Foi o que fiz, e faço, com o equívoco de memória. Mas vamos 
com calma, um passo de cada vez, digo que, por ora, basta a tentativa de formular um único conceito como risco suficiente para me fazer pensar um bocado. Por isso sugiro retomarmos essa conversa em outro momento para discutir as questões que ainda se mantêm sem resposta e aquelas relacionadas especificamente ao texto literário autobiográfico.

Acabo de levar mais um drible, eu suponho. De fato, ainda há muitas perguntas por fazer, mas concordo com a trégua proposta. No entanto, antes dela, há duas questões importantes que gostaria de fazer. A primeira é, na verdade, um pedido para que você dê algum exemplo concreto de como esse conceito de equívoco de memória pode se manifestar no texto literário.

Muito boa lembrança, por vezes esqueço da necessidade de mostrar em exemplos como se dá esse processo na prática da escrita literária.

Para não ser desonesto, confesso que a identificação, ou aquilo que poderia chamar aqui de exemplo, ainda é bastante limitada, tendo em vista que minha análise inicial tem sido realizada somente no texto Infância, de Graciliano Ramos (1977). Esse romance tem sido uma espécie de protótipo para o que pretende investigar em outras obras. Sei também que há várias e muito boas pesquisas sobre esse mesmo livro, mas, creio que se trata de um texto sobre o qual é sempre possível retornar com outros olhares e perguntas que talvez ainda não tenham sido feitas. No meu caso, e retomando o que havia dito no início, a ideia é verificar a presença desses vestígios, desses rastros da tradução do passado, e o modo como eles se apresentam na escrita do eu que narra o romance. Bom, vamos ao exemplo.

Há no livro, um capítulo intitulado "Um cinturão", em que o narrador conta um episódio em que o pai julga ter sido o menino, na época com quatro ou cinco anos segundo o texto, o responsável por esconder o tal cinturão e, como punição, aplica-lhe uma surra de chicote. A narrativa da personagem flutua entre o adulto que lembra e a criança assustada que, de tanto pavor, não é capaz de emitir nenhum som. Eis o trecho que, espero eu, sirva como resposta ao seu pedido de exemplo:

Não consigo reproduzir toda a cena. Juntando vagas lembranças dela a fatos que se deram depois, imagino os berros de meu pai, a zanga terrível, a minha tremura infeliz. Provavelmente fui sacudido. O assombro gelavame o sangue, escancarava-me os olhos (RAMOS, 1977, p. 33, grifos meus).

Logo no início, chama atenção a franqueza com que o narrador admite a incapacidade de rememorar tudo o que ocorreu. A sequência do parágrafo retoma e confirma essa confessa inabilidade ao conectar por meio da imaginação essas vagas lembranças aos fatos que se sucederam. Veja, aqui, esse elemento da imaginação, sobre o qual já havíamos falado anteriormente, torna-se o responsável pela conexão e pela recriação dessa memória, com certeza traumática. É graças a uma operação em que se utiliza de enxertos imaginativos tomados de situações posteriores que o narrador preenche as lacunas dessa memória. Já a palavra que 
inicia a penúltima frase é, para mim, elemento central para poder afirmar se tratar aqui do exercício de tradução do passado vindo à superfície. Perceba, o narrador poderia ter simplesmente optado pela supressão do advérbio provavelmente, mas o seu uso marca o exercício dessa tradução do episódio. $\mathrm{O}$ efeito do advérbio, em conjunto com as demais expressões de incerteza e vacilo contidas no parágrafo, torna o leitor cúmplice do movimento de tradução efetuado pelo narrador.

São em trechos como esses que afirmo ser possível enxergar o equívoco de memória, pois neles vêm à tona a profunda relação de alteridade entre o que se escreve sobre o que se quer lembrar e o fato tal como ocorreu, demonstrando a impossibilidade (nesse caso confessada explicitamente pelo narrador) de se rememorar o fato tal qual como ele se deu ao mesmo tempo que essa confissão é, ela própria a possibilidade de se ter acesso a essa memória.

\section{Interessante. No exemplo dado não é curioso que tenha aparecido a uma me-} mória traumática?

Sim, sem dúvida, e há no campo da Psicanálise, por exemplo, toda uma discussão possível sobre tal tema. Contudo, não me sinto preparado para fazê-la e para não correr o risco de falar besteira, prefiro dizer que dentro do contexto que analiso, o trauma pode também figurar nos momentos em que o narrador oscila, se confunde, hesita. Mas não quero dizer que isso é um efeito do trauma, mas que a forma como textualmente essa memória é traduzida pode apontar para algo cuja personagem não consegue externar de modo assertivo, deixando vestígios do esforço de sua tradução. Vestígio, aliás, é uma palavra importante. Aleida Assman discutindo esse vocábulo, escreve que "o problema da tradição [...] torna-se muito mais complexo no momento em que não se trata mais de anotar e ler contra o esquecimento, mas de incorporar esse esquecimento como elemento constitutivo no processo de transmitir e legar coisas do passado." (ASSMAN, 2011, p. 229, grifos da autora). O vestígio seria o elemento que, mesmo sob rasura, sob o signo do equívoco, da ambiguidade, põe a narrativa em relação com o passado. Não é possível analisar o vestígio onde não há sequer um índice legível, por isso a ideia do trauma, do lembrar "do/eu", como diz Tânia Ramos (1990), não deve ser abandonada, contudo, embora possa constituir o narrador autobiográfico, esse trauma deve, para fins de análise, figurar como forma, texto. Aliás, se me permite, há outro trecho de Infância que gostaria de citar porque traz essa ideia de vestígio:

Desse antigo verão que me alterou a vida restam ligeiros traços apenas. $E$ nem dêles (sic) posso afirmar que efetivamente recorde. O hábito me leva a criar um ambiente, imaginar fatos a que atribuo realidade. Sem dúvida as árvores se despojaram e enegreceram, o açude estancou, as porteiras dos currais se abriram, inúteis. É sempre assim. Contudo, ignoro se as plantas murchas e negras foram vistas nessa época ou em secas posteriores, e guardo na memória um açude cheio, coberto de aves brancas e flores (RAMOS, 1977, p. 26, grifos meus). 
A memória é caracterizada por "ligeiros traços" e a personagem reconhece ignorar se o que lembra pertence àquele tempo ou se é uma lembrança que se mistura à outra posterior. Aqui a escrita representa este esforço da memória que estou chamando de tradução e é justamente a presença desse esforço na superfície do texto que demonstra o compromisso ético em escancarar o equívoco, a impossibilidade da semelhança pretendida com o passado, senão pela diferença que estabelece uma relação com este passado ao mesmo tempo em que respeita a outridade do que já foi. Digo isso assumindo a perspectiva da personagem sem pôr em questão a vida do autor. Não ignoro, como já disse, o índice autoral da autobiografia, mas destaco que o foco de análise aqui é o modo como essa memória se organiza esteticamente na obra literária. Enfim, espero que os exemplos tenham sido satisfatórios.

Sim, acredito que foram de grande ajuda para a compreensão, na prática do que até então vínhamos discutindo. Essas análises me deixaram curioso, você teria outra passagem para mostrar?

Sim. Vejamos as palavras iniciais do romance "Infância":

A primeira coisa que guardei na memória foi um vaso de louça vidrada, cheio de pitombas, escondidas atrás de uma porta. Ignoro onde o vi, quando o vi, e se uma parte do caso remoto não desaguasse noutro posterior, julgá-lo-ia sonho. Talvez nem me recorde bem do vaso: é possível que a imagem, brilhante e esguia, permaneça por eu a ter comunicado a pessoas que a confirmaram. Assim, não conservo a lembrança de uma alfaia esquisita, mas a reprodução dela, corroborada por indivíduos que lhe fixaram o conteúdo e a forma. De qualquer modo a aparição deve ter sido real (RAMOS, 1977, p. 9, grifos meus).

Olhando para o texto é possível perceber a ideia de uma memória que está guardada, protegida, mas que se esvai e, exceto pela continuidade estabelecida com algo posterior, poderia não ter passado de um sonho. Em seguida aparece um advérbio que expressa dúvida, afetando o verbo seguinte, recordar, e nos fazendo desconfiar do narrador. Surgem então pessoas que confirmam a visão (sonho?) do menino que conta o que talvez lembre, o que deve ter sido real. Já não se trata mais de uma memória em que se possa confiar, todavia a relação está estabelecida, o esforço de tradução do passado se apresenta por meio das marcas que acabo de destacar. Quer acreditemos ou não na personagem, o vaso de pitombas está lá, escondido atrás da porta.

Há ainda uma referência à memória coletiva, quando a personagem diz poder acreditar na imagem do vaso porque outras pessoas confirmaram tal relato. Isso destaca o processo de alteridade pelo qual nos construímos como sujeitos. Lembro do tradutor Leonardo Fróes (2013, p. 102) citando uma frase do pintor gaúcho Carlos Scliar: “Eu sou você que me olha.. Está escrito no quadro diante do qual o espectador se coloca”. Tal afirmação corrobora o que penso a respeito 
da alteridade como elemento constitutivo do sujeito. A identidade não como semelhança, mas como diferença que funda uma relação é um princípio que está presente na perspectiva que apresento sobre a tradução, a memória e o próprio sujeito. O narrador autobiográfico se constitui pela linguagem de modo dialógico e traduz o passado em seu texto por meio do estabelecimento de uma relação com aquilo que lhe é alter porque é ali que uma relação se torna possível, é ali que a ética permite ao sujeito se inscrever sem sobrescrever ou apagar a outridade que lhe constitui. Gostaria de encerrar esta digressão citando Mikhail Bakhtin (2006) e a ideia de excedente de visão. Ele dirá que de onde estamos é impossível ver o que está às nossas costas, mas que de nosso ponto de vista podemos enxergar o que está às costas da pessoa à nossa frente, isso que vemos "a mais" seria o excedente de visão que cada um tem em relação ao outro e que, portanto, faltaria sempre a cada um de nós essa porção de excedente de visão que reside no outro e que nós, do lugar que ocupamos no mundo, somos incapazes de ver. Acho essa uma bela imagem para pensar sobre a alteridade que nos compõe.

Interessante. A alteridade realmente desempenha um papel importante dentro do seu esquema de pensamento. Mas para finalizarmos nossa conversa gostaria de lhe propor uma última questão que diz respeito ao diálogo com outros autores do campo da memória. Qual deles você utiliza para sustentar a sua tese?

Certo. Naturalmente o tema da memória possui já um longo percurso teórico, portanto poderíamos nos deter durante muito tempo nessa questão se fôssemos realizar uma espécie de retomada cronológica daqueles que sobre esse tema se debruçaram. Contudo posso falar, mais recentemente, da influência de Paul Ricoeur (2007) e da leitura que ele faz, por exemplo, de Edward Casey a respeito da memória como o reconhecimento de algo que é, ao mesmo tempo, ausente e anterior ao momento em que é lembrado. É nisso, inclusive, que baseio a minha compreensão do autor do texto autobiográfico como sendo duplamente outro, uma vez que difere tanto daquele $e u$ do passado (ausente e anterior) como do eu que escreve, pois à medida que o faz ele, autor, já está, a cada frase, deixando de ser o mesmo.

Outra ideia de Ricoeur que procuro adotar tem a ver com a compreensão da memória como única ferramenta de que dispomos para rememorar, o que faz com que ele considere os esforços dela na busca por uma fidelidade ou verdade como um valor intrínseco. Em outras palavras, é como se a memória agisse de boa-fé ao realizar o trabalho de recordar alguma coisa e, por isso, seria inerente a ela essa verdade ou fidelidade, uma vez que a busca em si pressupõe a possibilidade de encontrar o que se procura.

Posso citar também Michael Pollak (1992), autor que me auxilia no entendimento da memória como um aspecto importante na construção da identidade dos sujeitos. Desse modo, é possível entender que as personagens dos textos autobiográficos, ao narrarem suas vidas, se constroem a partir de uma sensação de coerência que une, de certa forma, o eu que escreve ao eu rememorado, procedi- 
mento que atesta os sentimentos de continuidade e de unidade dentro do tempo, elementos citados por Pollak como constitutivos da identidade. Ainda seguindo o pensamento desse autor, gostaria de destacar sua concepção de memória como fenômeno construído, resultado de uma seleção, consciente ou inconsciente, daquilo de que se quer lembrar. É a partir desse caráter de organização da memória que utilizo a expressão tradução do passado, procurando estabelecer a semelhança entre os procedimentos de seleção presentes tanto no ato de lembrar, tal como posto por Pollak (1992), quanto no de traduzir.

Outro autor que posso incluir na minha lista de cúmplices teóricos é Maurice Halbwachs (1990). É reconhecida a importante contribuição dele para o entendimento da memória como um fenômeno coletivo, atentando para o modo como as recordações estão ancoradas nos grupos aos quais pertencemos e às pessoas com as quais compartilhamos os acontecimentos de nossas vidas. Aliás, sobre o debate entre memória individual e coletiva, ao qual havia rapidamente aludido em uma resposta anterior, aproveito para registrar aqui uma reflexão importante, tendo em vista que Halbwachs (1990) tende a considerar a memória individual como que ligeiramente subordinada à experiência coletiva, sem a qual ela perderia sua ancoragem. Minha percepção, no entanto, é de que não há essa imposição do coletivo sobre o individual.

Mais uma vez recorrendo a Paul Ricoeur (2007), concordo com a posição do autor que, às categorias do eu (indivíduo) e dos outros (coletivo), adiciona uma terceira: a dos próximos. Nela, estariam inseridos a família, os amigos, os conhecidos, enfim, pessoas próximas capazes de oferecer pontos de referência para a rememoração do indivíduo e que poderiam também ser aqueles a quem a narração de determinadas memórias se dirige. A adição dessa categoria serve como uma ponte entre a memória individual e a coletiva, visto que esta última parece pertencer a uma esfera mais distante do sujeito. Dessa maneira, os próximos seriam os responsáveis por reconhecer a narrativa do indivíduo, seja para confirmá-la ou refutá-la.

Peço perdão mais uma vez por esse longo desvio, mas, em resumo, o que gostaria de afirmar é que no relato autobiográfico há uma dimensão coletiva, presente tanto nos acontecimentos rememorados como na própria tradução do passado que se dá por meio de um código comum, o da escrita, da linguagem "da qual é preciso dizer que é a língua dos outros" (RICOEUR, 2007, p. 138). E há também uma dimensão individual, presente no modo como esse relato se organiza, nas palavras que o narrador escolhe utilizar, nas situações que relata, na ordem em que as dispõe no seu texto. Por isso irei dizer que a tradução do passado no texto autobiográfico é resultado dessa articulação entre um movimento coletivo e individual.

Penso que esses seriam alguns dos autores que, por ora, poderia citar como referências para o que penso a respeito dos conceitos de memória. Se me permite, antes de finalizar, gostaria de explicar que quando falei há pouco desse sujeito que escolhe o que narrar não estou me referindo aqui à ideia de um sujeito dono de si e de suas ações. Obviamente dentro dos estudos da linguagem considerar a exis- 
tência desse tipo de sujeito é um erro. No entanto, o que destaco é o fato de que, no texto autobiográfico, não se pode negar a presença de um autor que organiza a sua obra e que tem sobre ela, com todas as ressalvas possíveis, certa autonomia. Bom, temo que essa minha última ressalva possa desencadear outra grande discussão para a qual não teremos tempo, visto que já me estendi demais nas explicações de sua última pergunta.

Sim, infelizmente essa, assim como outras importantes questões, terá que aguardar o fim da nossa trégua, como você propôs antes dessas ultimas duas respostas. Acredito que, por enquanto, já temos material suficiente para pensar até retomarmos essa conversa.

\section{Referências}

ASSMANN, A. Espaços da recordação: formas e transformações da memória cultural. Tradução de Paulo Soethe. Campinas: Editora da Unicamp, 2011.

BAKHTIN, M. (VOLOCHÍNOV, V. N). Marxismo e filosofia da linguagem. 12. ed. Tradução de Michel Lahud e Yara Frateschi Vieira. São Paulo: Hucitec, 2006.

BECHARA, E. Dicionário da Língua Portuguesa Evanildo Bechara. Rio de Janeiro: Nova Fronteira, 2011.

CANDIDO, A. Direito à literatura. In: CANDIDO, A. Vários escritos. Rio de Janeiro: Ouro sobre azul, 2011.p. 171-193.

COLASANTI, M. A moça tecelã. In: COLASANTI, M. Doze reis e a moça no labirinto do vento. São Paulo: Global, 2000. p. 10 -14.

EVARISTO, C. Becos da memória. 3. ed. Rio de Janeiro: Pallas, 2017.

FREIRE, P. Pedagogia do Oprimido. 17. ed. Rio de Janeiro: Paz e Terra, 1987.

FRÓES, Leonardo. Como diluir o eu pela escrita. In: NOVAES, Tiago (Org.). Tertúlia: o autor como leitor. São Paulo: Edições Sesc São Paulo, 2013. p. 83 - 102.

HALBWACHS, M. A memória coletiva. Tradução de Laurent Léon Schaffter. São Paulo: Vértice; Editora Revista dos Tribunais, 1990.

HALL, S. Cultura e representação. ITUASSU, A. (Org.). Tradução de Daniel Miranda e William Oliveira. Rio de Janeiro: Ed. PUC-Rio: Apicuri, 2016.

HOOKS, Bel. Ensinando a transgredir: a educação como prática da liberdade. Tradução de Marcelo Brandão Cipolla. São Paulo: Martins Fontes, 2013.

INSTITUTO HOUAISS (Org.). Dicionário Houaiss Conciso. Mauro de Salles Villar (Ed.). São Paulo: Moderna, 2011.

LARROSA BONDÍA, J. Notas sobre a experiência e o saber de experiência. Tradução de João Wanderley Geraldi. Revista Brasileira de Educação, Rio de Janeiro, n. 19, p. 20-28, jan./abr., 2002. DOI: https://doi.org/10.1590/S1413-24782002000100003.

LEJEUNE, P. O pacto autobiográfico. 2. ed. Tradução de Jovita Maria Gerheim Noronha e Maria Inês Coimbra Guedes. Belo Horizonte: Editora UFMG, 2014.

PLATÃO. Diálogos: Teeteto - Crátilo. Tradução de Carlos Alberto Nunes. Belém: UFPA, 1973.

POLLAK, M. Memória e Identidade Social. Transcrição e tradução de Monique Augras. Edição de Dora Rocha. Revista Estudos Históricos, Rio de Janeiro, v. 5, n. 10, p. 200-215, 1992. 
PROF. Paulo Freire. Palestra realizada no auditório do CDCC em 22 de novembro de 1994, patrocinada pelo IFSC-USP e Escola Educativa, 2014. Publicado pelo canal USP CDCC São Carlos. Disponível em: https://www.youtube.com/ watch?v=2C518zxDAo0. Acesso em 26 mai. 2021.

RAMOS, G. Infância. 12. ed. Rio de Janeiro: Record, 1977.

RAMOS, T. R. O. Meninas atrevidas: o que é que não vão dizer? Revista Tempo Brasileiro, Rio de Janeiro, v. 101, n. 21/28, p. 21-28, abr./jun., 1990.

RICOEUR, P. A memória, a história, e o esquecimento. Tradução de Alain François et al. Campinas: Editora da Unicamp, 2007.

SPIVAK, G. C. Tradução como cultura. Tradução de Eliana Ávila e Liane Schneider. Ilha do Desterro, Florianópolis, n. 48, p. 41-64, jan./jun., 2005. DOI: https://doi. org $/ 10.5007 / \% 25 x$.

VIVEIROS DE CASTRO, E. Equívocos de identidade. In: GONDAR, J.; DODABEI, V. (Orgs.). O que é memória social? Rio de Janeiro: Contra capa, 2005. p. 145 -160 .

Recebido em: 01/12/2020

Aceito em: 08/03/2021 